\title{
Poéticas de lo menor en el hispanismo transatlántico
}

y. Laura Scarano / Universidad Nacional de Mar del Plata - Conicet / laurarosanascarano@gmail.com

\section{Resumen}

Identidades alternas, intimidades históricas y afán de intervención en una trama transnacional son ejes que sostienen buena parte de las propuestas poéticas del siglo xxi dentro del marco de un hispanismo transatlántico, con un abanico de subjetividades, escenarios y narrativas, que oscilan entre las reivindicaciones de lo local y las inevitables servidumbres de lo global. La aguda conciencia de las lacras planetarias no anula la contundente reafirmación del espacio doméstico, los vínculos afectivos y la experiencia de la «privacy». Inmersos en los convulsionados escenarios neoliberales, los poetas abandonan las antiguas utopías mesiánicas de liberación, las consignas lexicalizadas y las filiaciones partidarias, pero rubrican la vigencia de una postura ética y estética en la escena social. Se trata de una matriz epistémica que he denominado en otros trabajos poéticas de lo menor, y que excede el acotado horizonte tradicional del género lírico, para situarse en la escena intelectual como una práctica discursiva abierta $\mathrm{e}$ integradora, renuente a ser catalogada desde las polarizadas taxonomías de géneros, naciones o territorios acotados. globalización • hispanismos transatlánticos $•$ culturas translocales

\section{Abstract}

Alternative identities, historical intimacy and testimonial desire, besides transnational issues are holding the poetics of this xxist century within the framework of a transatlantic hispanism, with a range of subjectivities, scenarios and narratives, ranging between the demands of the local and the inevitable global claims. The acute awareness of the planetary problems does not cancel the reaffirmation of the domestic space, values and emotional bondes, the individual experience of "the privacy". Immersed in the tumultuous neoliberal scenarios, the poets have already left messianic utopias of liberation, slogans and party affiliations, but endorse the validity of aesthetic posture of intervention in the social field. This trend evolves to an epistemic field which I called poetics of the minor, which exceeds the limited traditional horizons of lyrical genre, and constitute a discursive practice open and integrative, far from polarized taxonomies such as gender, nation, territory.

Key words: poeticas of the minor - xxist Century • globalization $\cdot$ transatlantic hispanism $\cdot$ translocal cultures 